\title{
HOMOGENIZATION OF AN Al-Mg ALLOY AND ALLIGATORING FAILURE: ALLOY DUCTILITY AND FRACTURE
}

\author{
HOMOGENIZACIJA Al-Mg ZLITINE IN KROKODILJENJE: \\ DUKTILNOST ZLITINE IN PRELOM
}

\author{
Endre Romhanji, Tamara Radetić, Miljana Popović \\ University of Belgrade, Faculty of Technology and Metallurgy, Department of Metallurgical Engineering, \\ Karnegijeva 4, POB 35-03, 11120 Belgrade, Serbia \\ endre@tmf.bg.ac.rs \\ Prejem rokopisa - received: 2015-06-01; sprejem za objavo - accepted for publication: 2015-06-12
}

doi:10.17222/mit.2015.110

\begin{abstract}
High-strength Al-Mg alloys have a propensity toward hot fracture and failure by alligatoring during hot rolling. In this study the effect of homogenization conditions on the susceptibility of an Al-5.1Mg- $0.7 \mathrm{Mn}$ alloy toward alligatoring was investigated. It was found that the plates homogenized in a temperature range of $460-520{ }^{\circ} \mathrm{C}$ were prone toward alligatoring, but once homogenized at $550{ }^{\circ} \mathrm{C}$ they were not prone toward it any longer. The characterization of the fracture showed a predominance of the intergranular ductile fracture, but the type of the constitutive particles filling the voids changed with the homogenization regime. Grain decohesion and grain-boundary embrittlement show that certain thermal treatments resulted in a microstructure that promoted slip localization.

Keywords: Al-Mg alloy, thermo-mechanical processing, hot working, ductility, embrittlement
\end{abstract}

Pri Al-Mg zlitinah z visoko trdnostjo se med vročim valjanjem pogosto pojavijo razpoke in krokodiljenje. V študiji je bil preiskovan vpliv pogojev pri homogenizaciji na občutljivost zlitine Al-5,1Mg-0,7Mn na krokodiljenje. Ugotovljeno je, da so plošče, ki so bile homogenizirane v temperaturnem območju $460-520{ }^{\circ} \mathrm{C}$, občutljive na pojav krokodiljenja, medtem ko plošče plosce, ki so bile homogenizirane v temperaturnem območju $460-520{ }^{\circ} \mathrm{C}$, obcutljive na pojav krokodiljenja, medtem ko plošč prelom, vendar pa se je z režimom homogenizacije spreminjala tudi vrsta delcev v jamicah. Dekohezija med zrni in krhkost po mejah zrn kažeta, da se določena toplotna obdelava odraža na mikrostrukturi, ki lokalizira drsenje.

Ključne besede: Al-Mg zlitina, termomehanska predelava, vroča predelava, duktilnost, krhkost

\section{INTRODUCTION}

One of the main concerns in the fabrication of highstrength $\mathrm{Al}-\mathrm{Mg}$ alloy sheets is their proclivity toward hot fracture and formation of defects such as edge cracking, central bursts and alligatoring during hot rolling. ${ }^{1,2}$ The alligatoring defect is characterized by an opening of rolled slab ends due to a crack formation along the central horizontal plane of the slab. In addition to the inefficiencies associated with the material loss, the failure caused by it can introduce serious damage to the equipment.

It is considered that alligatoring arises due to an inhomogeneous deformation and a variation in the residual-stress states across the width of a rolled material. ${ }^{3}$ The modeling based on the upper-bound approach allowed the development of the criteria for its occurrence in terms of the roll-gap shape factor, $\Delta=h / l$ ( $h$ is the average sheet thickness of the rolling gap, $l$ is the arc of contact). ${ }^{4}$ The prediction of a failure due to the alligatoring taking place at $\Delta>1.35$ was verified by cold rolling an Al6061-T6 alloy. However, other reports show alligatoring taking place at $\Delta$ of $0.5-1.5 .^{1,2}$ Some studies $^{5,6}$ consider the development of a sharp notch at the concave front of a slab and the resulting triaxial state of the stress at the notch tip to be responsible for the failure. Similarly, the presence of a complex state of the stress and the concave shape of the front end of a slab play important roles in the alligatoring during the cold rolling of spheroidized steel. ${ }^{7}$

However, the effects of other factors, such as homogenization conditions and the microstructures of the Al-Mg alloys, on the alligatoring are far less understood. This work reports about the effect of the homogenization conditions on the occurrence of the alligatoring in an Al-5.1Mg-0.7Mn alloy during hot-rolling experiments.

\section{EXPERIMENTAL WORK}

The material used in this study was an Al-Mg alloy with higher $\mathrm{Mg}$ and $\mathrm{Zn}$ contents than a standard AA 5083 alloy; its composition was within the lower limits of an AA 5059 alloy (Table 1). The alloy, supplied by Impol-Seval Rolling Mill-Serbia, was industrially DC cast.

Prior to hot rolling, plates $25 \mathrm{~mm} \times 30 \mathrm{~mm} \times 55 \mathrm{~mm}$ were homogenized, following one of the regimes given in Figure 1. Hot rolling was performed at a two-high rolling mill (a roll diameter of $200 \mathrm{~mm}$ ). The applied schedule of hot-rolling passes $\left(n_{\mathrm{i}}, i=1-8\right)$ was designed by gradually increasing the reduction from $1.5 \%$ in the 
E. ROMHANJI et al.: HOMOGENIZATION OF AN Al-Mg ALLOY AND ALLIGATORING FAILURE

Table 1: Chemical compositions of the studied alloy and standard AA 5083 and AA 5059 alloys, in mass fractions (w/\%) Tabela 1: Kemijska sestava uporabljene zlitine in zlitini AA 5083 in AA 5059 po standardu, v masnih deležih (w/\%)

\begin{tabular}{|c|c|c|c|c|c|c|c|c|c|c|}
\hline & $\mathrm{Mg}$ & $\mathrm{Mn}$ & $\mathrm{Cu}$ & $\mathrm{Fe}$ & $\mathrm{Si}$ & $\mathrm{Zn}$ & $\mathrm{Cr}$ & $\mathrm{Ti}$ & $\mathrm{Sr}$ & $\mathrm{Zr}$ \\
\hline Alloy & 5.13 & .72 & .013 & .34 & .11 & .51 & .008 & .025 & .003 & - \\
\hline AA5083 & $4.0-4.9$ & 0.4-1.0 & $<.1$ & $<.4$ & $<.4$ & $<.25$ & $0.05-0.25$ & $<.15$ & $<.005$ & $<0.05$ \\
\hline AA5059 & $5.0-6.0$ & $0.6-1.2$ & $<.25$ & $<.5$ & $<.45$ & $.4-.9$ & $<0.25$ & $<.2$ & $<0.05$ & $0.05-0.25$ \\
\hline
\end{tabular}

Table 2: Hot-rolling outcome and characteristic parameters after the homogenization treatments

Tabela 2: Stanje po vročem valjanju in značilni parametri po homogenizaciji

\begin{tabular}{|c|c|c|c|c|c|c|}
\hline \multirow[b]{2}{*}{ Homogenization procedure } & \multirow[b]{2}{*}{ Outcome } & \multirow{2}{*}{$\begin{array}{c}h_{0} \\
(\mathrm{~mm})\end{array}$} & \multirow{2}{*}{$\begin{array}{c}h_{\mathrm{f}} \\
(\mathrm{mm})\end{array}$} & \multirow{2}{*}{$\begin{array}{l}\text { Total } \\
\text { reduction } \\
(\%)\end{array}$} & \multicolumn{2}{|c|}{ "Alligatoring" pass } \\
\hline & & & & & $\begin{array}{l}\text { Partial reduction } \\
(\%)\end{array}$ & $h / l$ \\
\hline \multirow{2}{*}{$\begin{array}{c}\text { Regime I } \\
460^{\circ} \mathrm{C} / 16 \mathrm{~h} \rightarrow \mathrm{HR}\end{array}$} & Alligatoring & 20.4 & 14.6 & 28.4 & 18 & 0.90 \\
\hline & Alligatoring & 20.4 & 13.7 & 32.8 & 19 & 0.86 \\
\hline \multirow{4}{*}{$\begin{array}{c}\text { Regime II } \\
430{ }^{\circ} \mathrm{C} / 12 \mathrm{~h}+520{ }^{\circ} \mathrm{C} / 16 \mathrm{~h} \\
\text { Cooling } \rightarrow 500^{\circ} \mathrm{C} / 1 \mathrm{~h} \rightarrow \mathrm{HR}\end{array}$} & Alligatoring & 25 & 13.5 & 46.0 & 20 & 0.82 \\
\hline & Alligatoring & 25 & 14.0 & 44.0 & 18 & 0.89 \\
\hline & Success & 25 & 6.5 & 74.0 & l & 1 \\
\hline & Alligatoring & 21 & 11.8 & 43.0 & 20 & 0.76 \\
\hline \multirow{4}{*}{$\begin{array}{c}\text { Regime III } \\
430{ }^{\circ} \mathrm{C} / 12 \mathrm{~h}+550{ }^{\circ} \mathrm{C} / 16 \mathrm{~h} \\
\text { Cooling } \rightarrow 500{ }^{\circ} \mathrm{C} / 1 \mathrm{~h} \rightarrow \mathrm{HR}\end{array}$} & Success & 25 & 6.0 & 76.0 & I & / \\
\hline & Success & 25 & 6.1 & 75.6 & I & I \\
\hline & Success & 25 & 6.0 & 76.0 & I & 1 \\
\hline & Success & 21 & 7.0 & 67.6 & I & 1 \\
\hline
\end{tabular}

first pass to $35 \%$ at the end (Figure 1). The temperature of the plates at the exit of each pass was in a $380-400{ }^{\circ} \mathrm{C}$ range. After each rolling pass, the plate was reheated for $10 \mathrm{~min}$.

SEM characterization of the fractured surfaces was conducted with JEOL JSM-6610LV at $20 \mathrm{kV}$, equipped with an EDS detector and Tescan Mira 3XMU at $10 \mathrm{kV}$.

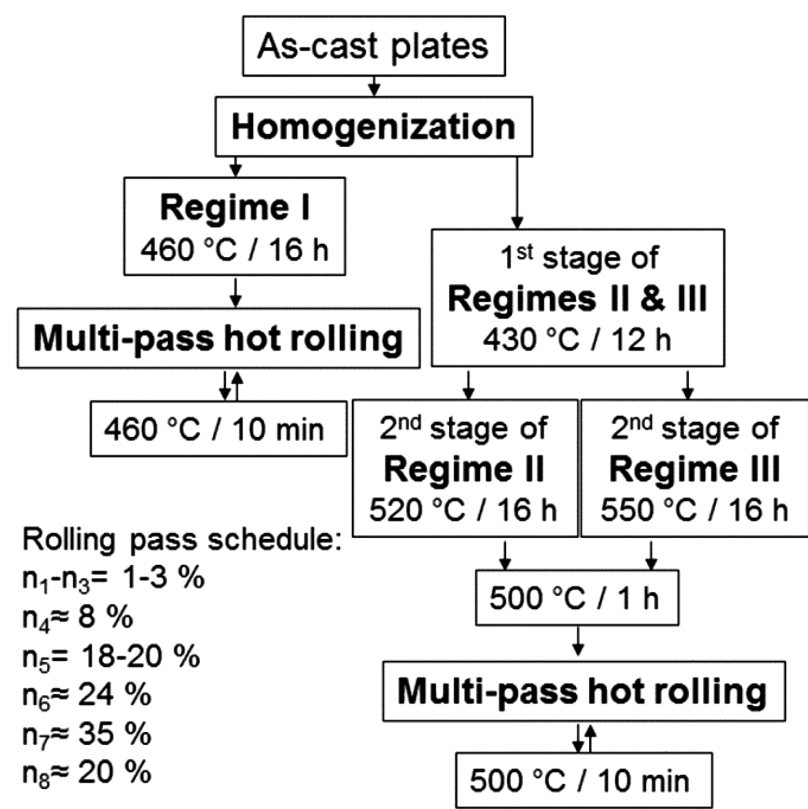

Figure 1: Schematic representation of the thermo-mechanical treatment: homogenization and hot-rolling schedules

Slika 1: Shematski prikaz termo-mehanske obdelave: potek homogenizacije in vročega valjanja

\section{RESULTS}

\subsection{Hot rolling}

The effects of different homogenization treatments on the hot-rolling outcome are shown in Table 2. The hot rolling of the plates homogenized according to Regimes I and II failed due to the alligatoring. The critical passes corresponded to the partial reductions of $\approx 20 \%$. The alligator crack (Figure 2a) opened at the front side in all the cases.

The total reduction for the plates homogenized following Regime I was $\approx 30 \%$, while $\Delta$ was $0.85-0.90$ at the failure pass.

The hot rolling of three out of four plates homogenized according to Regime II failed. In the passes leading to the alligatoring, $\Delta$ was in a range of $0.76-0.89$. However, the plates homogenized according to Regime II showed higher hot ductility than in the case of Regime I since the total reduction at failure was $\approx 45 \%$.

The plates homogenized at the highest temperature (Regime III) did not alligator and all of them were suc-
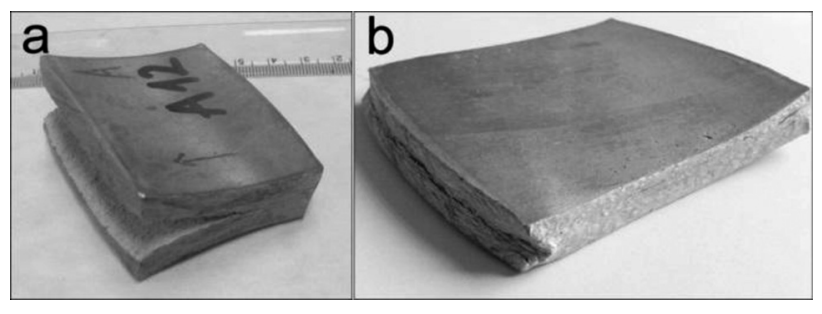

Figure 2: a) Image of an alligatoring defect after hot rolling with the total reduction of $44 \%$, b) concave front profile of the plate that did not alligator (total reduction of $74 \%$ )

Slika 2: a) Posnetek napake krokodiljenja po vročem valjanju s celotno redukcijo $44 \%$, b) konkavni sprednji del plošče, kjer ni bilo krokodiljenja (celotna redukcija $74 \%$ ) 


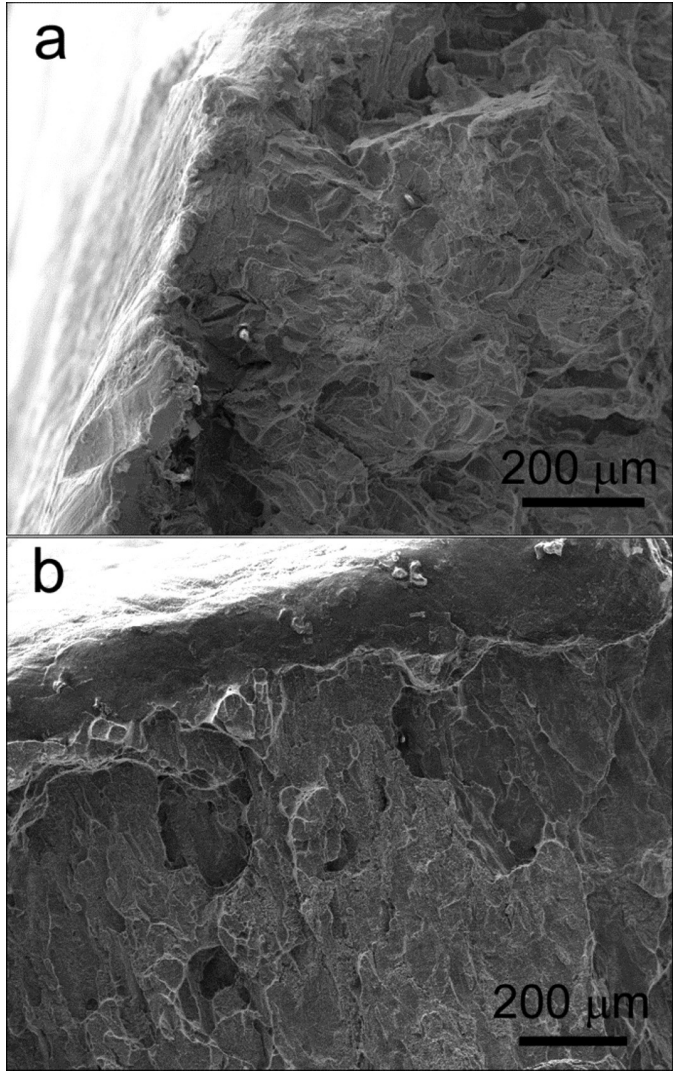

Figure 3: Secondary-electron SEM micrographs of the front edge of a plate: a) Regime I, b) Regime II

Slika 3: SEM-posnetek prednjega roba plošče s sekundarnimi elektroni: a) Režim I, b) Režim II

cessfully hot rolled with a total reduction of up to $\approx 70-75 \%$.

The fronts of the plates developed a concave profile during the hot rolling, with the formation of a groove at the centerline as the deformation progressed (Figure 2b). The shape of the side profile varied with the position along a slab. Some lateral spreading was observed at high total reductions.

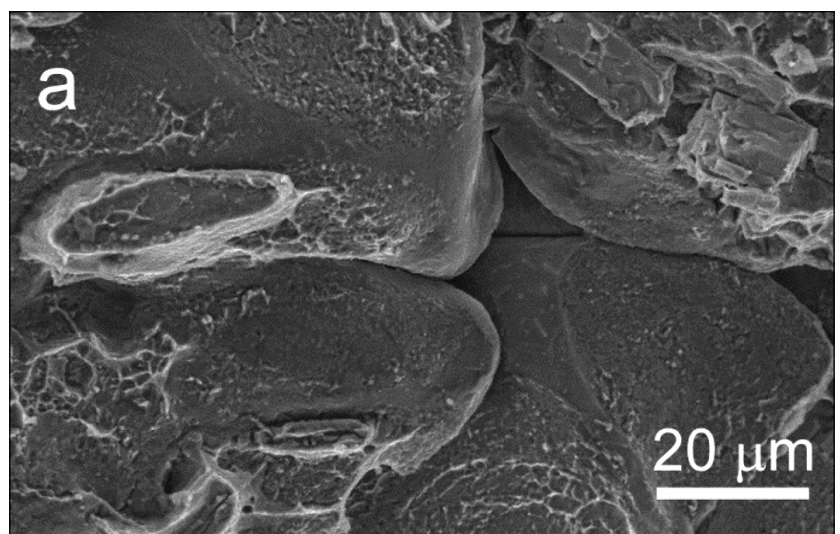

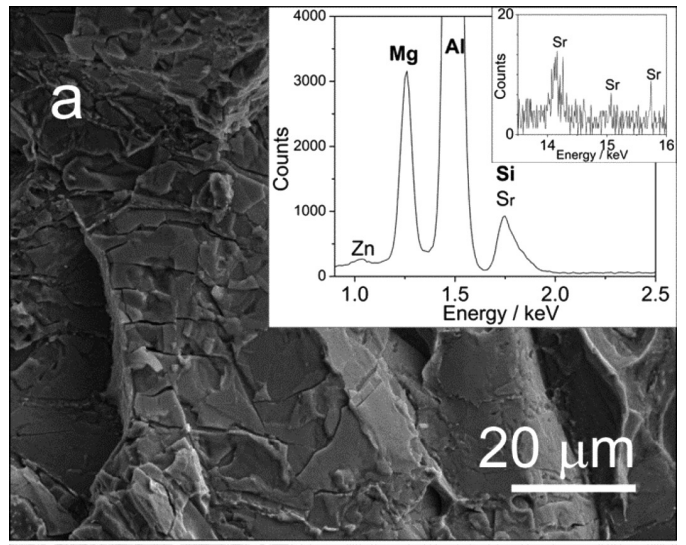

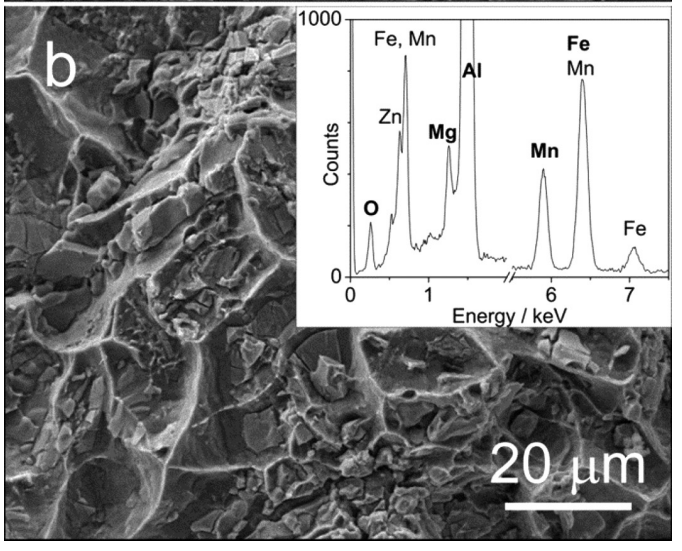

Figure 4: Secondary-electron SEM micrographs of ductile intergranular fractures and EDS of the broken constitutive particles: a) Regime I, b) Regime II

Slika 4: SEM-posnetek s sekundarnimi elektroni duktilnega, interkristalnega preloma in EDS-analiza polomljenega delca: a) Režim I, b) Režim II

\subsection{Fractography}

A macroscopic examination of the fracture surfaces revealed two distinct regions, similarly to the report on spheroidized steel. ${ }^{7}$ The narrow region at the front edge of a fractured plate, 1-2 $\mathrm{mm}$ in width, was characterized

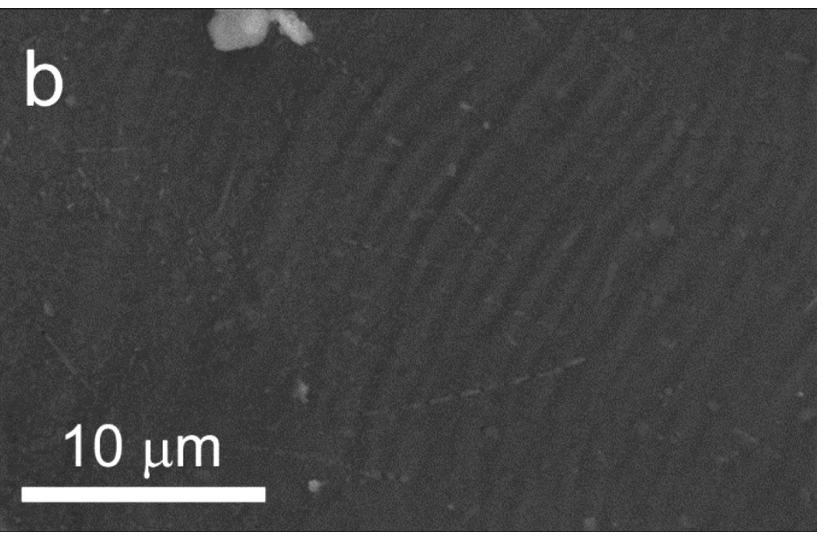

Figure 5: Secondary-electron SEM micrographs of a brittle intergranular fracture (Regime I): a) smooth grain surfaces, b) slip-line traces and shearing of dispersoids

Slika 5: SEM-posnetek s sekundarnimi elektroni krhkega, interkristalnega preloma (Režim I) : a) gladka površina zrn, b) sledovi drsnih linij in striženje disperzoidov 


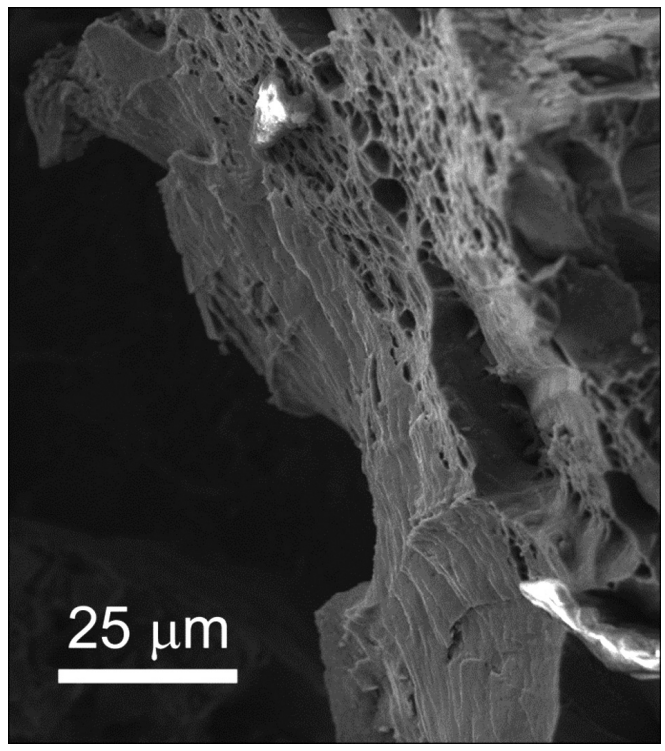

Figure 6: Secondary-electron SEM micrograph of a cleavage (Regime I) Slika 6: SEM-posnetek s sekundarnimi elektroni cepilnega loma (Režim I)

with a number of ridges consisting of high elevations and depressions. It was more prominent on the plates homogenized according to Regime II than Regime I. The topography of the rest of the fracture was more leveled. A dull surface typical of a ductile fracture was sprinkled with tiny sparkles indicating the presence of cleavage facets.

A SEM characterization of the plates homogenized according to Regime I showed that the fractured surface extended to the very end of the front edge (Figure 3a). A hem, with markings from the front side of the plate, was observed only at a few points.

On the plates homogenized according to Regime II, the hem with the front-side marks extended over the entire front edge, being 100-200 $\mu \mathrm{m}$ wide (Figure 3b). Adjacent to it was a region of shallow, elongated dimples that is characteristic for a shear fracture and void sheeting. Away from the edge, the predominant fracture mode was ductile intergranular fracture for all the alligatored plates (Figure 4).

An intergranular fracture proceeded due to a coalescence of voids created by a break-up of constitutive particles. However, there was a distinction between the broken constituent particles filling the voids, depending on the homogenization regime. Most of the particles of the plates homogenized according to Regime I had a thin plate-like morphology (Figure 4a). The EDS analysis showed that those particles were a $\mathrm{Mg}-\mathrm{Si}-\mathrm{Sr}$ rich phase. On the plates homogenized according to Regime II, a mixture of a plate like $\mathrm{Mg}-\mathrm{Si}-\mathrm{Sr}$ and more irregularly shaped $\mathrm{Al}_{6}(\mathrm{Fe}, \mathrm{Mn})$ was observed (Figure 4b).

Another difference was that a grain decohesion and a brittle intergranular fracture were observed only on the plates homogenized according to Regime I. Smooth grain surfaces of the brittle intergranular fracture par- tially covered with fine dimples nucleated at grainboundary dispersoids are shown in Figure 5.

A cleavage, with a typical river pattern (Figure 6), was observed on the plates homogenized according to both Regime I and II.

\section{DISCUSSION}

A failure by alligatoring is frequently ascribed to a deformation inhomogeneity across the plate cross-section due to a low reduction and an induced distribution of stresses. ${ }^{1-4}$ The results of this study, i.e., the alligatoring occurring at high reductions of $20 \%$ and $\Delta=0.75-0.9$, show that it may not be critical. Rather, the state of the stress leading to the alligatoring might be related to the metal flow in the roll gap. The lateral spread along the centerline was greater than in the surface layer due to the friction at the roll surfaces leading to a groove formation at the front. ${ }^{5}$ The groove could have acted as a notch and provided a stress concentration for the crack initiation. ${ }^{5,6}$ However, the results show that the grooving is unlikely the sole cause of the alligatoring. On the plates homogenized according to Regime II, the fracture by the void sheeting adjacent to the groove (Figure 3a) is a sign of shear stresses and a low stress triaxiality. ${ }^{8}$

Furthermore, the deepest grooves were observed on the plates that did not fail during the hot rolling. On the other hand, on the least ductile plates, homogenized according to Regime I, incipient grooving was observed only at a few points along the front profile. Since deformation conditions were identical for all the plates, but the material response varied with the homogenization treatment (Table 2), it is clear that different ductilities and predispositions toward the alligatoring were related to the microstructures developed during the thermal treatment. Fracture features such as the change in the type of the constitutive particles filling the voids point in that direction. The observed grain decohesion and grain-boundary embrittlement can be related to the slip localization and dispersoid distribution that will be described in Part II of this study.

\section{CONCLUSION}

It was demonstrated that ductility and predisposition toward alligatoring during hot rolling depend on the homogenization treatment of the $\mathrm{Al}-5.1 \mathrm{Mg}-0.7 \mathrm{Mn}$ alloy. An increase in the homogenization temperature improved the ductility and the plates homogenized at $550{ }^{\circ} \mathrm{C}$ (Regime III) did not alligator. Ductile intergranular fracture is the dominant fracture mechanism, but on the plates homogenized at the lowest temperature (Regime I), grain decohesion and brittle intergranular fracture were also observed. Changes in the fracture mode and the type of the constitutive particles broken with the homogenization treatment pointed out that the propensity 
toward alligatoring is controlled by microstructural changes.

\section{Acknowledgment}

This research was supported by the Ministry of Education, Science and Technological Development, Republic of Serbia, and Impol-Seval Aluminium Rolling Mill, Sevojno, under contract grant TR 34018.

\section{REFERENCES}

${ }^{1}$ M. M. Al-Mousawi, A. M. Daragheh, S. K. Ghosh, D. K. Harrison, Some physical defects in metal forming processes and creation of a data base, Journal of Materials Processing Technology, 32 (1992) 1-2, 461-70, doi:10.1016/0924-0136(92)90202-4

${ }^{2}$ J. G. Lenard, Workability and Process Design in Rolling, In: G. Dieter, H. A. Kuhn, S. L. Semiatin (eds.), Handbook of Workability and Process Design, ASM International, Materials Park, Ohio, USA 2003, 258-277
${ }^{3}$ J. A. Schey, Fracture in rolling processes, Journal of Applied Metalworking, 1 (1980) 2, 48-59, doi:10.1007/BF02833609

${ }^{4} \mathrm{~S}$. Turczyn, The effect of the roll-gap shape factor on internal defects in rolling, Journal of Materials Processing Technology, 60 (1996) 1-4, 275-282, doi:10.1016/0924-0136(96)02342-4

${ }^{5}$ A. J. Meadows, W. J. Pearson, Discussion: Edge Cracking, Lamination, and Surface Cracking in Hot and Cold Rolling, Journal of the Institute of Metals, 92 (1964) 8, 254-255

${ }^{6}$ R. Couch, R. Becker, M. Rhee, M. Lee, Development of a rolling process design tool for use in improving hot roll slab recovery, Report UCRL-TR-206843 (2004), Lawrence Livermore National Laboratory, USA 2004; available at https://e-reports-ext.1ln1.gov/pdf/ 312127.pdf

${ }^{7}$ L. Xu, G. S. Daehn, Alligatoring and damage in the cold rolling of spheroidized steels, Metallurgical and Materials Transactions A, 25 (1994) 3, 589-598, doi:10.1007/BF02651600

${ }^{8}$ F. Bron, J. Besson, A. Pineau, Ductile rupture in thin sheets of two grades of 2024 aluminium alloy, Materials Science and Engineering, 380A (2004) 1-2, 356-364, doi:10.1016/j.msea.2004.04.008 